white line down the centre, anterior margin pale, at the side a black dot; third segment with two posterior, triangular, brown spots divided by a fine white interval; anteriorly and towards each side is a pointed black dot, and a black dot on each side; fourth segment with two black dots somewhat removed from the centre, and on the side one similar black dot; the anal segment with a nearly quadrate black patch, and a small black dot at the base of the short anal legs. Six pectoral legs pale brownish, eight ventral and two anal legs the colour of the body. Feeds on the leaves of Stellaria holostea (fig. $3 \mathrm{~b}$ ), which thereby become discoloured.

Last autumn Messrs. Grant and Dunning found several of the cases at Putney on Stellaria holostea, and the larva lived through the winter. In April this year, Mr. Stainton discovered the larvæ on the same plant growing in hedges at Lewisham. The specific name has proved to be singularly inappropriate, for the larvæ are quite gregarious, five or six being commonly seen on a shoot of the plant Stellaria: but they are difficult to rear.

Imago (fig. $3 \mathrm{c}$ ) appears in July. Zeller described this species from a single specimen bred from a case found by him attached to grass; it is very rare in collections in this country.

\title{
XIII. Notes on the Development of Osmia parietina, and other British Insects. By F. Sмıтн, Esq.
}

[Read August 2nd, 1852.]

IN the ninth volume of the "Zoologist" I published some account of the habits of Osmia parietina, a little bee which had selected the under side of a stone on which to affix the balls of pollen on which to deposit its eggs. This stone was discovered in early spring on the Grampian Hills, near Perth, too early in the season for any of the brood to have issued from the cocoons. At the time of its discovery about one-third of the cocoons were empty, showing that at least that portion of the mass had been developed during the previous season. The only difficulty was this-had the parent bee or bees deposited on the same stone two successive seasons? The stone came into my possession in the autumn of 1851 ; and in the month of November, finding that a number of the cocoons were still unopened, I cut one or two in such a manner that $I$ could raise as it were a trap-door and watch the progress of the bees. All that I opened contained larvæ. After closing them, and carefully preventing the admission of air, vol. II. N. S. PART III. - DEC. 1852. 
I left them undisturbed until the month of April of the present year. I found them at that time still in the larva state, in which they remained until the beginning of June, when they changed to pupæ. On the fourth of July a male came forth, and subsequently a female. The rest perished in the cocoons during my absence in the country, having been exposed to the intense heat of the sun. This was a matter of little consequence; an important discovery had been made. A portion of the deposit of eggs made in 1849 had been three years in arriving at their perfect development. It were vain, in my opinion, to attempt to account for the circumstance. In the first instance, the whole mass of eggs had been subject to the same influences, and had produced larvæ, some of which had become perfect bees in 1850 -others in 1851 , - - leaving about twenty-five out of 230 , about the original number, to be developed in 1852. This, I believe, is the first instance on record of such a circumstance occurring in the aculeate Hymenoptera, although numerous instances have, I believe, been observed in other orders. I have before noticed the non-development of numerous individuals out of a quantity of the larvæ of Anthophora retusa during the first season; and any one who will examine a colony of Anthophora in the month of November will find both larvæ and perfect insects. Circumstances such as I have recorded may serve in some measure to account for the abundance or scarcity of certain species during different seasons; but I must confess myself quite unable to advance any opinion as to the cause of this arrest of development.

I feel that $\mathrm{I}$ am justified in stating 1849 as the time when the deposit of eggs took place, and I believe it to have been made by several bees using the same spot for that purpose. It is clear that in 1850 about one-third were developed, and a portion having been retarded until 1852, I think it a fair presumption that the whole deposit was made in the same and not in successive seasons.

In the month of March last I observed that many young shoots of the aspen, in Turner's Wood, Hampstead, were much swollen, at distances varying from four to six or eight inches apart,-on splitting them, I found a channel, varying from three to four inches in length, up the middle of the stick; at the extremity of which was either the larva of a longicorn beetle, or that of some dipterous insect; in one or two instances I found the dipterous larva within the dried skin of that of the longicorn; the dipterous larvæ were as ten to one of that of the longicorn. From these shoots, which I kept exposed to all the vicissitudes of the weather, during the first week in May the flies began to appear, and proved to be Tachina 
nitidula. The longicorn Saperda populnea did not appear until the second week in June.

Many Entomologists, like myself, must have observed towards the end of summer those little cartridge-like rolls on the leaves of young oaks in woods, \&c. and have understood them to be the production of Attelabus curculionoides ; my impression was, that if so, they were formed by the larvæ of that insect as a nidus, in which to undergo their transformations. I have now succeeded in satisfying myself that I was mistaken in this particular,-they are formed by the perfect insect. I found these leaf-rolls in great numbers in Yorkshire, in July, also the perfect insect; and, although I did not observe them in the act of rolling them, still, on unrolling many recently formed, I found an egg of a yellow colour.

Last year, in the month of September, I found the leaf-rolls very abundant in a wood near Hampstead, and collected as many as would fill a half pint measure ; after opening about twenty, all of which were empty, I found one containing a full-grown larva. I placed the rest in a flowerpot, on mould, leaving them exposed to the weather until the month of April, when I covered the pot with fine net, and about the middle of the month of May, I had several specimens of Attelabus developed, but a much larger number of a species of Chalcididous insect, which will probably in some measure account for the small number of Attelabus developed, as compared with the number of cases collected. I found on digging into the mould that the larva had buried itself to undergo its transformations.

Last year, 1851, in the month of May, I observed numbers of a little wood-boring beetle, Scolytus destructor, busily engaged in burrowing in the bark of an elm branch. In autumn I cut off a portion, in order that I might observe their transformations; on examining the progress of the insect in April following, I found the beetle still in the larva state. At the extremity of every sixth or eighth gallery formed by the Scolytus, I observed a small Hymenopterous larva. About the end of May the beetles began to appear, and also a number of a small Chalcididous insect,Cheiropachus quadrum.

From another piece of wood, containing the larvæ of Ptilinus pectinicornis, I bred numbers of another parasite, also belonging to the Chalcidida,-Caloseter vernalis.

I have also, again, bred specimens of a species of Hylaeus from 
a bramble stick; the larvæ were five in number, placed at about half a line apart, without any separation constructed between them, in fact exactly agreeing with the description which I published of Hylaus signatus five years ago; but, as far as I know, it was Mr. Thwaites who first proved the Hylai to be working bees, and the subsequent observations of myself, and also of $\mathrm{Mr}$. S. Saunders, have confirmed his observations, made in 1841. The species which I have bred this year is my own, Hylaus hyalinalus.

XIV. Descriptions of some new Species of the Coleopterous Family Paussidæ, with a Synopsis of the Family. By J. O. Westwood, Esq., F.L.S.

[Read 2nd August, 1852.]

HAving already on several occasions brought under the notice of the Entomological Society the very remarkable insects composing the family Paussida, I should have hesitated in again doing so were not the additions which I purpose describing in the present paper of considerable importance. The description of a single species, and that not even a novelty in science, may, it is true, be rendered most worthy of attention when treated by a Reaumur, a Lyonnet or an Audouin, but the zoological, technical descriptions of a few isolated species can scarcely expect to obtain notice. In the present instance, however, although so short a time has elapsed since I published a revised and extensively-illustrated Monograph of the Paussida in the second volume of my "Arcana Entomologica" (1845, containing fifty-three species), together with the addition of ten new species subsequently described in our Transactions and Proceedings, and seventeen new species in the Proceedings of the Linnæan Society, I am able by the exertions of several friends to extend the limits of the family still further; and now that the natural habits of the insects have been discovered, there is likely - to use a very poor pun-to be no pause in the discovery of new species of Paussida. Major Champion, for instance, discovered several specimens belonging to two distinct new species under a single stone at Hong Kong, and Mr. Benson found so many specimens of P. Parrianus in their natural haunts at the Cape of Good Hope, that he was able at leisure to watch their habits in detail. (See Trans. Ent. Soc. vol. v. p. 30.)

The species recently described, and those now for the first time noticed, form portions of collections made by different collectors in various parts of Asia, Africa and Australia. Of these a consi- 


\section{$2 \mathrm{BHL}$ Biodiversity Heritage Library}

Smith, Frederick. 1852. "XIII. Notes on the Development of Osmia parietina, and other British Insects." Transactions of the Entomological Society of London 7, 81-84. https://doi.org/10.1111/j.1365-2311.1852.tb02213.x.

View This Item Online: https://www.biodiversitylibrary.org/item/51245

DOI: https://doi.org/10.1111/j.1365-2311.1852.tb02213.x

Permalink: https://www.biodiversitylibrary.org/partpdf/35347

\section{Holding Institution}

Smithsonian Libraries

\section{Sponsored by}

Smithsonian

\section{Copyright \& Reuse}

Copyright Status: Public domain. The BHL considers that this work is no longer under copyright protection.

This document was created from content at the Biodiversity Heritage Library, the world's largest open access digital library for biodiversity literature and archives. Visit BHL at https://www.biodiversitylibrary.org. 